\title{
SOME THOUGHTS ON TICK-BORNE FEVERS IN THE MIDDLE EAST
}

\author{
Major R. N. P. SUTTON, M.A., D.M., D.C.H., R.A.M.C. (T.A.V.R.) \\ King's College Hospital, London. \\ Lieutenant-Colonel M. J. TEMPLER, M.R.C.P., M.R.C.P.E., R.A.M.C. \\ British Military Hospital, Hong Kong
}

\section{Introduction}

RELAPSING fevers of unknown origin are frequently encountered in tropical and subtropical areas and the chance observation of a small epidemic in Cyprus prompted the following remarks on the possible aetiologies of such fevers, with particular reference to the Middle East.

During May 1970, we saw several soldiers who, whilst on an exercise, had slept in small caves, had been bitten by ticks and had subsequently developed a febrile illness. They did not have any rash, apart from the tick-bite lesions; splenomegaly was not observed; and there was no apparent involvement of the central nervous system: The pyrexia was of a relapsing type. No spirochaetes or other parasites were seen in blood films taken at the height of fever, either on dark-ground examination or subsequent examination of stained films. Routine bacteriological investigation was unhelpful in diagnosis and, unfortunately, attempts at virus isolation and tests for virus antibodies were not possible. The patients recovered uneventfully and returned to duty; the episodes were not life-threatening but they incapacitated the affected men for some weeks. More recently there has been at least one instance (Vella, Personal Communication) of illness in a soldier stationed in Cyprus which apparently followed an 'insect bite' and where a virological aetiology was suspected.

There are three main possibilities in the differential diagnosis of febrile illness as seen in these patients.

These are:-

(a) Tick-borne Relapsing Fever. (b) Q Fever. (c) Arbovirus infection.

Tick-borne relapsing fever and $\mathrm{Q}$ fever are well-known entities and may be dismissed shortly. Arbovirus infection remains an open possibility and our present knowledge makes it one of considerable interest.

\section{Tick-borne relapsing fever}

Throughout the Eastern Mediterranean region, tick-borne relapsing fever has been recognised for decades as a cause of febrile illness. Infection is probably endemic in the civilian population but localised epidemics occur and many of these have been in soldiers. Thus Nicholson (1919) and Morrison (1937) described tick-borne relapsing fever in Palestine; Cooper (1942) described this condition in Tobruk and, more recently, Eisenberg, Gunders and Cohen (1968) have recorded cases where infection was acquired following the exploration of caves in the Judaean foothills. In Cyprus, tick-borne relapsing fever has been well documented (Coghill, 1949; Gambles and Coghill, 1948; Coghill and Gambles, 1948), Borrelia persica being the responsible organism with Ornithodorus tholozani as vector. In Coghill's series of 35 military patients, the clinical 
picture was more severe than that in the patients whom we saw and the diagnosis was readily made by the identification of spirochaetes in blood films, although it was admitted that these were often scanty; even during the febrile stage, and this was also remarked upon by Eisenberg, Gunders and Cohen (1968).

\section{$Q$ fever}

The clinical and epidemiological features of infection with Coxiella burneti are well known and $\mathrm{Q}$ fever is only mentioned here as, although commonly transmitted by aerosol and by infected milk, it is primarily a zoonosis and infection may be acquired from infected animals via infected ticks. The frequent pulmonary involvement and presentation as a primary atypical pneumonia (Caughey and Dudgeon, 1947) differ somewhat from the picture seen in our patients, although the presence of $Q$ fever in Cyprus has been discussed by Gillespie (1951).

\section{Infection with arboviruses}

Infections with arboviruses affect non-immune individuals who enter endemic zones; hence a military population is, pur excellence, one at risk. From an epidemiological point of view, such infections may be classified according as to whether the vectors are mosquitoes, sandffies or ticks. Although, in our cases, infection with a tick-borne virus might be suspected, infection with viruses transmitted by other vectors cannot be entirely ruled out and, indeed, the transmission of mosquito-borne viruses by ticks may occur. if only (as with West Nile virus) in an experimental situation (Whitman and Aitken, 1960).

\section{Mosquito borne arbovirus infections}

Infections with dengue (transmitted by Aedes aegypti) and West Nile (transmitted by Culex modestus) viruses are known to be widespread in the Mediterranean area. There is evidence of this (antibodies in man and animals, recovery of viruses) in Greece (Pavlatos and Smith, 1964), Israel (Nir, Lasawski, Avivi and Goldwasser, 1966; Akov and Goldwasser, 1966; Bernkopf, Levine and Nerson, 1953), the Lebanon (Garabedian, Matossian and Musalli, 1971) Italy (Balducci, Veroni, Lopes and Gregorig, 1967) and the South of France (Hannoun, Corniou and Carrigue, 1969; Panthier, Hannoun, Beytour and Mouchet, 1968; Hannoun, Panthier, Mouchet and Eouzan, 1964).

Interest in the dengue viruses, of which there are four serotypes, has increased with the recognition that they, together with chikungunya virus, may be responsible for severe haemorrhagic illnesses as well as the mild infections which are more commonly observed. Such haemorrhagic fevers have been described in South East Asia and in India (Hammon, Rudnick and Sather, 1960; Myers and Carey, 1967; Shah, Gibbs and Banerjee, 1964; Myers, Carey, Rodrigues and Klontz, 1964). Although not seen recently, such severe manifestations of dengue virus infection were described in the 19271928 epidemic in Greece (Pantano, 1928) which was due, in all probability, to dengue type 1 virus (Theiler, Casals and Moutousses, 1960).

The survey of Mediterranean migratory birds carried out by the Yale Arbovirus Research Unit in conjunction with the Smithsonian Institute has demonstrated the presence of infection with West Nile virus (by recovery of virus and presence of antibody) in migrating birds captured in Cyprus and in Egypt (YARU annual reports, 1968, 
1969; Watson, Shope and Kaiser, 1969). The same study also demonstrated that infection with the less well known mosquito-borne viruses Ingwavuma (Bunyamwera super-group) and with strains of the Simbu group also occurred.

Recent developments in tissue culture techniques (Bergold and Mazzali, 1968; Stim, 1969) have facilitated the handling of these viruses in the laboratory and have greatly lessened the dependence upon mice.

\section{Sandfy fever}

Febrile illness in the Mediterranean area, resulting from infection with the phlebotomus fever group of viruses, has been recognised for many years. More recently, viruses have been recovered in South and Central America, the Middle East and in Nigeria, which are serologically related to the pristine Naples and Sicilian strains of phlebotomus fever virus (YARU annual report, 1968). These have been recovered from rodents, as well as from man and sandflies which heretofore seemed to be the sole hosts, and this poses a question as to the role of rodents as a reservoir of virus in the Mediterranean area. As with the mosquito-borne viruses, recent developments have facilitated epidemiological studies with these rather difficult viruses (Bergold and Mazzali, 1968; Stim, 1969; Salim 1967).

\section{Tick-borne virus infections}

A voluminous literature exists, much of which is from Eastern Europe, concerning the tick-borne viruses of man and their ecology (Hoogstraal, 1966, 1970; Blascovic, 1961, 1967; Smith, 1962, 1964, 1968). These viruses are found in many areas, both tropical and temperate, including France (Hannoun, Corniou and Rageau, 1970) and Italy (Sacca, Mastrilli, Balducci, Verani and Lopes, 1969). They may be responsible for febrile illness, encephalitis and for haemorrhagic fevers, according to the particular virus. During the past few years, some interesting aspects of their ecology have been recognised which may well throw light on the cases of febrile illness which we observed in Cyprus.

During the autumn, vast migrations of birds take place from Northern Europe, across the Mediterranean, to Africa. It has been estimated (Moreau, 1961) that about 600 million birds may be involved; of these, perhaps 2-3 per cent are infested with ticks and each bird may bear 1 to 2 ticks (Hoogstraal, Kaiser, Traylor, Gaber and Guindy, 1961; Hoogstraal, Kaiser, Traylor, Guindy and Gabor, 1963; Nuorteva and Hoogstraal, 1963). Clearly these provide a tremendous potential for the dispersal of pathogenic organisms infecting ticks and/or birds. A proportion of these birds are viraemic and, of birds captured in the Nile delta or in Cyprus (some 25 miles from the area where our patients were bitten by ticks), 45 of 3,300 yielded agents which were pathogenic for mice--that is, presumptive arboviruses - (Watson, Shope and Kaiser, 1969). These agents included West Nile virus, strains of Bahig virus and strains related to Quaranfil, Uukuniemi. Kemerovo and Simbu groups and Ingwavuma virus. These are viruses which have also been recovered from mosquitoes (Simbu group, Ingwavuma; West Nile) and from ticks (Uukuniemi, Bahig, Quaranfil, Kemerovo). Many of these birds possessed antibodies to a range of arboviruses and, in individual species, where such antibodies were detected, up to 10 per cent (commonly about 5 per cent) showed such evidence of previous infection. 


\section{Disciussion}

To most clinicians, a history of relapsing fever associated with tick bite would be tantamount to a diagnosis of classical tick-borne Relapsing Fever. Knowledge of the occasional failure to demonstrate Borrelia microscopically in the blood in proved cases of this infection and the absence of useful diagnostic serological tests have tended to perpetuate such diagnoses, even when laboratory tests are negative. There is now considerable evidence that certain arboviruses are present in the Middle East and that they should be considered as a cause of fever in this area. Confirmation of arbovirus infection depends upon laboratory studies and, in the past, these were laborious and necessitated large colonies of mice in which virus recoveries and serelogical tests could be carried out. These difficulties have been lessened by the use of tissue cultures.

The arboviruses are a group, diverse in ecology, whose role in nature is still being unfolded. They may produce illness in indigenous inhabitants but are much more likely to produce disease in susceptible immigrants. Such disease may range from mild fevers to fatal encephalitis or haemorrhagic fevers. These viruses are found, not only in exotic tropical areas, but also in areas such as the Mediterranean basin which are frequented by susceptible tourists and others. They are potential hazards and deserve our attention.

\section{Acknowledgements}

I am grateful to Professor A. C. Cunliffe, Doctors W. G. Downs and H. Hoogstraal, for much help in many ways.

\section{REFERENCES}

Akov, Y. and Goldwasser, R. (1966). Bull. Wld: Hith Org. 34, 901.

Balducci, M., Veroni, P., Lopes, M. and Gregorig, B. (1967). Amer. J. trop. Med. Hyg. $16,211$.

BERGOLd, G. H. and MAZzali, R. (1968). J. gen. Virol. 2, 273.

Bernkopf, H., LeVINe, S. and Nerson, R. (1953). J. infect. Dis. 93, 207.

Blaskovic, D. (1961). Trans. N.Y. Acad. Sci. 23, 215.

Blaskovic, D. (1967). Bull. Wld Hith Org. 36, (supp. 1), 5.

Caughey, J. E. and Dudgeon, J. A. (1947). Brit. med. J. ii, 684.

Coghill, N. F. and Gambles, R. M. (1948). Ann. trop. Med. Parasit. 42, 113.

Coghill, N. F. (1949). J. roy. Army med. Cps. 93, 2.

COOPER, E. L. (1942). Med. J. Aust. i, 635.

Eisenberg, S., Gunders, A. E. and CoHEN, A. M. (1968). Trans, roy. Soc. trop. Med. Hyg. $62,679$.

Garabedian, G. A., Matossian, R. M. and Musalli, M. N. (1971). J. med. liban. $24,339$.

Gambles, R. M. and Coghill, N. F. (1948). Ann. trop. Med. Parasit. 42, 288.

Gillespie, J. E. O'N (1951). Cyprus med. J. 4, 758.

Hammon, W. McD., Rudnick, A. and Sather, G. E. (1960). Science 131, 1102.

Hannoun, C., Corniou, B. and Garrigue, G. (1969). Revue de L'Instut. Pasteur de Lyon 2, 1.

Hannoun, C., Corniou, B. and Rageau, J. (1970). Acta virol. 14, 167.

Hannoun, C:, Panthier, R., Mouchet, J. and Eouzan, J. P. (1964). C.R. Acad. Sci. (Paris) $256,4170$.

HoogstraAl, H. (1966). Ann. Rev. Entomology 11, 261.

HoogstraAl, H. (1970). Bibliography of Ticks and Tick-borne Disease. NAMRU-3, Cairo.

Hoogstraal, H., Kaiser, M. N., Traylor, M. A., Gaber, S. and Guindy, E. (1961). Bull. Wld Hith Org. 24, 197.

Hoogstraal, H., Kaiser, M. N., Traylor, M. A., Guindy, E. and Gaber, S. (1963). Bull. Wld Hith Org. 28, -235 .

Moreau, R. E. (1961). Ibis. $103 a$ 373, 580.

Morkison, R. J. G. (1937). J. roy. Army med. Corps 68, 86.

Myers, R. M. and CAReY, D. E., Rodrigues, F. M. and Klontz, C. E. (1964). Indian J. med. Res. $52,559$.

MYers, R. M. and CAREY, D. E. (1967). Science 157, 1307.

Nicholson, F. D. (1919). Brit. med. J. ii, 811.

NiR; Y., Goldwasser, R., Lasowski, Y. and Avivi, A. (1967). Amer. J. Epidem. 86, 372.

Nir, Y., Lasowski, Y., Avivi, A. and GoldwaSser, R. (1966). Amer. J. trop. Med. Hyg. $18,416$.

Nuorteva, P. and Hoogstraal, H. (1963). Ann. Med. exp. Fenn. 41, 457.

Panthier, R., Hannoun, C., Beytout, D. and Mouchet, J. (1968). Ann. Inst. Pasteur 115, 433.

Pavlatos, M. and Smith, C. E. G. (1964). Trans, roy. Soc. trop. Med. Hyg. 58, 422. 
Pontano, T. (1928). La Pandemia di Dengue in Atene. Policlinico (cited by D. H. Clarke and J. Casals in Viral and Rickettsial Diseases of Man. Ed. by F. L. Horsfall and I. Tamm. Philadelphia 1965).

Sacca, G., Mastilli, M. L., Balducci, M., Veroni, P. and Lopes, M. C. (1969). Ann. Inst. Sup. Sanita. 5,21 .

Salim, A. R. (1967). Amer. J. trop. Med. Hyg. 16, 92.

SHAH, K. V., GiBRS, C. J. and BANERJEe, G. (1964). Indian J. med. Res. 52, 676.

SmITH, C. E. G. (1964). Factors Influencing the Behaviour of Viruses in Their Arthropodan Hosts. In: Host Parasite Relationships in Invertebrate Hosts. 2nd Symposium of the British Society for Parasitology.

SMITH, C. E. G. (1968). Abstr. Hyg. 43, 1397.

Smith, C. E. G. (1962). Ticks and Viruses. Symposium. Zoological Society of London.

STIM, T. B. (1969). J. gen. Virol. 5, 329.

Theiler, M., CAsals, J. and Moutousses, C. (1960). Proc. Soc. exp. Biol. (N.Y.) 103, 244.

WATSON, G. E., SHOPE, R. E. and KAISER, M. N. (1969). An Ectoparasite and Virus Survey of Migratory Birds in the Eastern Mediterranean. Paper read at the Symposium for the Study of the Role of Migratory-Birds in the Distribution of Arboviruses, Akademgorok, Novisbirsk, U.S.S.R.

Whitman, L. and Aitken, T. H. G. (1960). Ann. trop. Med. Parasit. 54, 192.

YALE Arbovirus Research Unit Annual Report 1968, Pp. 46-50.

YALE Arbovirus Research Unit Annual Report 1969, Pp. 18-28.

\section{Honorary Consultant}

Mr. T. L. T. Lewis, M.B., F.R.C.S., F.R.C.O.G., has been appointed Honorary Consultant in Obsterics and Gynaecology to the Army with effect from 15 May 1973, in succession to Mr. A. H. Charles who is retiring.

\section{Order of St. John of Jerusalem}

Those recently appointed to, or promoted in, the Most Venerable Order of the Hospital of St. John of Jerusalem include:

As Officer (Brother)

Brigadier J. F. D. Murphy, Q.H.P., M.D., F.R.C.Psych., D.P.M. Colonel J. M. Adam, O.B.E., M.B., Ch.B. Colonel T. S. Hart, M.B., B.S., M.F.C.M., D.P.H., D.T.M.\&.H. Colonel D. S. Paton, M.B.E., M.B., Ch.B., M.F.C.M. Colonel J. A. Brunt, A.M.B.I.M. Lieutenant-Colonel A. C. Ticehurst, M.B., B.S. p.s.c.

\section{Guthrie Memorial Medal}

The Guthrie Memorial Medal for 1973 has been awarded to Professor J. G. Scadding, M.D., F.R.C.P., Honorary Consultant in Diseases of the Chest to the Army from 1953 to 1972 . 